\title{
Živalski frazemi v štajerskem južnopohorskem narečju ${ }^{1}$
}

\author{
ZINKA ZORKO \\ ANJA BENKO \\ Slovenska akademija znanosti in umetnosti, Ljubljana; \\ Univerza v Mariboru, Filozofska fakulteta, Koroška cesta 160, \\ SI-2000 Maribor,anja.benko@gmail.com
}

\begin{abstract}
V razpravi sta na glasoslovni ravni predstavljena štajerska južnopohorska govora Mislinje in Oplotnice, saj je mislinjski govor štajerski in ne koroški, kot je vrisano na Karti slovenskih narečij Tineta Logarja in Jakoba Riglerja (1993). Raziskovanje frazeologije kot jezikovne vede se je začelo v 70-ih letih dvajsetega stoletja. Tako imenovana živalska frazeologija predstavlja živali, živeče $\mathrm{v}$ domačem in tujem okolju. Živalski frazemi so zapisani v oplotniškem govoru in izpisani iz Pleteršnikovega Slovensko-nemškega slovarja (1894).
\end{abstract}

The paper discusses the Styrian South Pohorje dialects of Mislinja and Oplotnica. On the phonological level, the Mislinja dialect belongs to the Styrian and not Carinthian dialect as proposed by the maps in Tone Logar and Jakob Rigler's 1993 Karta slovenskih narečij. Phraseology research as a science on its own started evolving in the 1970s. The field of animal phraseology deals with the animals living in their domestic as well as other (i. e. wild) environments. The culled animal phrasemes are written in the Oplotnica dialect and collected from the Pleteršnik's 1894 Slovensko-nemški slovar.

Ključne besede: živalski frazemi, štajersko južnopohorsko narečje, narečno glasoslovje, narečni frazemi, knjižni frazemi, živalski frazemi v Pleteršnikovem Slovensko-nemškem slovarju

Key words: animal phraseme, the Styrian South Pohorje dialect, dialectal phonology, dialectal phrasemes, literary Slovene phrasemes, animal phrasemes in Pleteršnik’s Slovensko-nemški slovar

${ }^{1}$ Besedilo je bilo pripravljeno z vnašalnim sistemom ZRCola (http://ZRCola.zrc-sazu.si), ki ga je na Znanstvenoraziskovalnem centru SAZU v Ljubljani (http://www.zrc-sazu.si) razvil dr. Peter Weiss. 


\section{Uvod}

Frazeologija kot jezikovna veda preučuje besedne zveze s prenesenim pomenom in je nauk o stalnih besednih zvezah. Raziskovanje slovenske frazeologije se je začelo v 70-ih letih 20. stoletja v delih Jožeta Toporišiča.

Frazem velja za osnovno enoto frazeologije. Njegove lastnosti so večbesednost za točno določen pomen, stalnost oblike in pomena, neizpeljivost pomena iz sestavin zveze in ekspresivnost. Poznamo samostalniške, pridevniške, glagolske, prislovne, medmetne, členkovne, vezniške in predložne frazeme. S svojo ekspresivnostjo so vedno zaznamovano jezikovno sredstvo. Njihovo pogostost rabe je zaslediti v umetnostnih in neumetnostnih besedilih, pa tudi v vsakdanjem sporazumevanju v različnih govornih položajih.

Tako imenovana živalska frazeologija predstavlja živali, živeče v domačem okolju (živeče s človekom in ne živeče s človekom), in živali, ki jih človek najbolje pozna, v frazeologiji pa ne nastopajo le kot primerjalna fizična pojavnost ali lastnost, ki se ji pripisuje, ampak je frazeološko prenesen na človeka tudi način njihovega obnašanja.

\section{Južnopohorsko narečje}

Večja središča štajerskega južnopohorskega narečja so: Mislinja, Vitanje, Zreče, Slovenske Konjice, Oplotnica in Slovenska Bistrica.

Govor kraja Mislinja je na Karti slovenskih narečij (1993) vrisan kot koroški mežiški govor, raziskave v zadnjih letih pa dokazujejo, da je to prehodno štajersko narečje. Zaradi tega bo na kratko predstavljen najprej mislinjski govor, temeljna teoretična podstava razprave na vseh jezikovnih ravninah pa temelji na oplotniškem govoru.

\subsection{Mislinjski govor}

Na Karti slovenskih narečij (1993) je mislinjski govor na vzhodni meji koroškega mežiškega narečja ob štajerskih južnopohorskih govorih in štajerskem srednjesavinjskem narečju. Današnja narečna podoba govora Mislinje v glasoslovju kaže na štajersko podstavo.

Kraj se prvič omenja leta 1335 kot del slovenjegraškega gospodstva. Od leta 1998 je Mislinja občina, ki obsega 122 km² s 4600 prebivalci. Fužine so začele obratovati leta 1724 in 1754 prešle v last Michelangela Zoisa, podedoval jih je sin, baron Žiga Zois. Rudo so kopali na Pohorju v okolici Vitanja, oglje pa so žgali v gozdovih visoko nad Mislinjo. Po letu 1900 se je razvila tudi lesna industrija: žage, tovarna lepenke, sodarna, zabojarna. Že iz antičnih časov je znan promet skozi Mislinjo v Stari trg in na Gospo Sveto, v srednjem veku pa se je tod razmahnilo tovorništvo. 
SAMOGLASNIŠKI SISTEM je podoben južnopohorskemu s tipičnima štajerskima dvoglasnikoma: e:i in o: $u$, ki sta nastala iz stalno dolgega jata in dolgega cirkuflektiranega etimološkega $e$ ter iz dolgega cirkumflektiranega $o$ in iz dolgega samoglasniškega mislinjski samoglasniški sistem sestavljajo dolgo in kratko naglašeni samoglasniki ter nenaglašeni samoglasniki, ki so dobro ohranjeni.

DOLGI SAMOGLASNIŠKI SISTEM sestavljajo:

i:li:i

e:

$e: i$

e:lee: u: $/ u: u$

$o:$

o:u

o:/uo:

$+a r:$

\section{GRADIVO ZA DOLGE SAMOGLASNIKE}

Dolgi i:/i:i zastopa stalno dolgi i: 'list, 'pi:išem, 'si:ito, 'zi:iña.

Dolgi $u: / u: u$ je refleks za dolgi cirkumflektirani in staroakutirani $u$ : 'lu:čl 'lu:uč, 'lu:pim/'lu:upim, k'ru:xa/k'ru:uxa.

Dolgi ozki ẹ: zastopa staroakutirani jat, stalno dolgi nosni $e$, dolgi polglasnik in novoakutirani e: b'rẹ:za, 'le:to, ne'vẹsta; g'le:dam, 'pẹt, p'rẹ:dem; 'dẹ:n, 'vẹ:s, 'pẹ:sji; 'nẹ:so, 'pẹ:ko, 'zẹ:le.

Dolgi ozki $o:$ je refleks za dolgi nosni $Q$ in novoakutirani etimološki $o: k^{\prime} l o: p$, 'go:ba, 'to:ča; 'no:jsim, ško:da, 'vo:la.

Dolgi dvoglasnik e:i zastopa stalno dolgi jat in dolgi cirkumflektirani etimološki e: 'le:is, m'le:inko, s've:iča, s'merix, z've:izda; 'le:int, 'pe:ič.

Dolgi dvoglasnik o:u je refleks za dolgi cirkumflektirani $o$ in za dolgi zlogotvorni ț: 'bo:ug, 'mo:unč, 'no:unč; 'čorun, 'dorug, 'voruk, 'žo:una.

Široki e:/e e: zastopa umično naglašeni $e$ in kratki naglašeni polglasnik: 'če:lo/ 'čeerlo, 'ne:sem/'neersem, 'te:tal'teerta, 'pers/'peers.

Široki or je refleks za stalno dolgi $a$ : d'vor, x'rorst, ko'vo:č, p'ro:x. (Tega refleksa mežiško narečje ne pozna.)

Dvoglasnik uo: zastopa umično naglašeni o: 'kuo:za, 'uorsa, 'vuorda.

Dolgi $a$ : je refleks za staroakutirani $a$ in za dolgi $a$ : ob zvočniku $r$ : b'ra:ta, g'ra:d, 'nais.

Samoglasniški $r$ se izgovarja kot dolgi ar:: c'var:, 'čar:n, 'dar', s'mar't.

KRATKI NAGLAŠENI SAMOGLASNIKI so: $i, u, e, \partial, o, a$. Nastali so iz starih in novih akutiranih samoglasnikov. Kratki polglasnik je nastal najpogosteje iz kratkega $i$, po moderni vokalni redukciji pa tudi iz $e, o, u, a$.

NENAGLAŠENI SAMOGLASNIKI redko onemevajo. Pojavlja se tudi zlogotvorni t, zlasti v prevzetih besedah.

SOGLASNIŠKI SISTEM se od knjižnega loči le v nekaterih premenah. Gradivo zanje: 
- končni -l se izgovarja kot ur/u:u: 'dẹ:lou, su'širiun, o'bu:u, '̌́u:u;

- končni -al se izgovarja kot o: 'nẹiso;

- mehčani $l j$ je izgubil mehčanost in se izgovarja kot $l$ : k'ro:l, s'tẹ:la, 'vọ:la, 'zẹ:le, 'ze:mla;

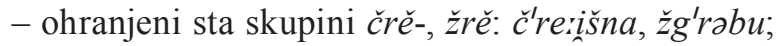

- v besedi z nosnim $n$ se pojavlja sekundarna nazalizacija: m'leinhko, 'mo:nka, 'mo:unč, 'no:unč, s'ne:ĭgk; to je tipični štajerski južnopohorski pojav;

- mehčani $n j$ izgublja nazalni element sredi besede, na koncu besede pa palatalnega: ka'me:je, s'vi:ja, zna'me:je; 'ni'va, 'lu:kna;

- zvočnik $v$ je pred samoglasniki zobnoustnični $v$, na koncu besede pa dvoustnični -u: 'vi:no, č're:iva, údo'u; pred začetnima $u$ - in $o$ - se izgovarja kot proteza: 'vuš, 'voxo, 'vuo:kno, 'vorign, 'vona 'ona', 'vuo:rex;

- zvočnik $j$ se lahko vriva pred $d, g$, s: 'xọjdim, 'o:jstro, t'ro:jsit;

- ohranjena sta sklopa - $d l$ - in - $d n-:$ 'modttt, 'mẹ:dnce;

- končni -g se izgovarja kot pripornik $x$ : 'bo:ux, p'ro:x 'prag';

- velar $k$ lahko nastane tudi iz $t$ : 'kẹ:dno 'teden', 'kẹ:tna 'veriga', $k$ 'lorčit 'tlačiti', t'rẹ:ki 'tretji';

- sklop dn prehaja v gn: g'narr;

- na koroški vpliv kaže prehod zloga -vi- v j: p'rajim 'pravim'.

\subsection{Oplotniški govor}

Štajerski govori poznajo le padajoče intonirane zloge, naglašeni zlog je ekspiratorično močan in tonično visok, poznajo naglasne pomike, kratko naglašeni fonemi se daljšajo, znana je sekundarna nazalizacija vokalov.

Zgodovinski podatki za Oplotnico pričajo, da je bilo ozemlje tod obljudeno Že v 3. tisočletju pred našim štetjem, o sami naselitvi Slovanov pa ni podatkov. Kraj je bil prvič omenjen leta 1182 .

\section{SAMOGLASNIŠKI SESTAV}

Govor kaže nagnjenje k diftongizaciji dolgih vokalnih fonemov, enoglasniki pa so srednje dolgi, vendar jih označujemo z dvopičjem, saj sta kratko naglašena le polglasnik, ki je nastal iz dvoglasniškega ẹ $i$, in $a$, nastal iz diftonga $a: i, a^{\prime} u$ ob zvočnikih in nezvočniških zapornikih.

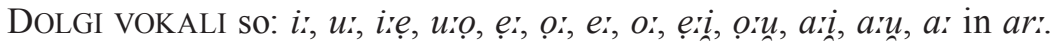

Vokal $i$; je zastopnik staroakutiranega jata, novoakutiranega etimološkega $e$, kratko naglašenega $i$ in umično naglašenega $i$. Gradivo: b'rirza, 'cirsta, 'di:lo, ne'vista, 'ri:bre, st'rixa; 'si:dn, 'zi:le; 'mi.š, 'ni:nč, 'ni:t; 'širrok, 'čìnki 'majčken', 'fi:rtux, 'li:dar.

Vokal $u$ : zastopa novoakutirani $o$, kratko naglašeni $u$ in umično naglašeni u. Gradivo: 'xu:ja, 'nu:ret 'vinograd', 'nuisism, š'ku:da, 'vu:la; k'ru:x, 'ju:žna 'malica'; po'suišeno, 'uižge se. 
Dvoglasnik i:e je refleks za sekundarno naglašeni $e$, novoakutirani $e$ v zadnjem zlogu in za umično naglašeni polglasnik. Gradivo: 'čiệlo, 'riệkla, 'tiẹta; k'mirẹt, 'ni:ẹt; 'čiẹbar, 'mirẹla.

Dvoglasnik uro zastopa umično naglašeni $o$ in novoakutirani $o$ v zadnjem zlogu. Gradivo: 'durobro, 'kưonec, 'kuroza, 'nuroga, 'urosa, k'rurop, 'kuioš.

Dolgi ozki ẹ: je refleks za dolgi cirkumflektirani polglasnik, za novoakutirani polglasnik v nezadnjem besednem zlogu, za stalno dolgi in za staroakutirani nosni ę. Gradivo: 'dẹ:n, 'lẹ:n, 'vẹss; 'mẹ:ša, 'pẹssji, 'gẹ:ne se; g'lẹ:dam, i'mẹ:na, 'pẹ:tek, p'lẹ:šsem.

Dolgi ozki o: zastopa praslovanski stalno dolgi in staroakutirani nosni $Q$ ter umično naglašeni o. Gradivo: 'go:bec, go'lo:p, k'lo:p, 'mo:š́, 'orzek, 'sọt, 'go:ba, 'rọ:ka; 'xọdlla je, 'po:znam, s'kọ́čla.

Dolgi široki e: je nastal kot položajna varianta po poenoglašanju dvoglasnika a:j v zaprtem zlogu. Gradivo: 'be:ta 'bajta', 'ce:t 'čas', 'e:dova 'mo:ka 'ajdova moka'; na'ze: 'nazaj', 're:ni 'rajni.'

Dolgi široki or je refleks za dolgi a:. Gradivo: d'vor, g'lorva, x'rorst, kọ'vorč, 'mo:liga, p'ro:x, p'roivi, s'to:ra, t'ro:va.

Dvoglasnik ẹ:i je nastal iz dolgega $i$. Gradivo: doma'čẹnini, 'gẹ:iva 'iva',

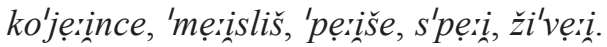

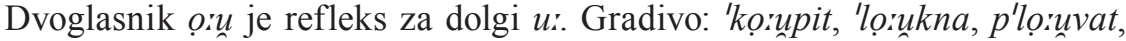
'sọ:ux, 'tọ:ulila.

Dvoglasnik a: $i$ je nastal iz stalno dolgega jata in iz dolgega cirkumflektira-

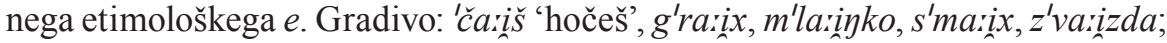
čre'vaizsa, ko'la:ise, 'parič.

Dvoglasnik a:u je naslednik dolgega cirkumflektiranega etimološkega $o$. Gradivo: 'ba:uk, 'da:u 'kdo', 'ga:ut, 'ka:us.

Dolgi $a$ : je refleks za kratko naglašeni $a$ in za umično naglašeni $a$. Gradivo: b'la:, b'rait, 'ka:t, k'lait.

Samoglasniški $r$ se izgovarja kot ar:. Gradivo: 'bar'cno, brezs'kar'bn, 'dar've, 'parrvi, u'mar:, '̌̌ar'.

Izvorno KRATKI NAGLAŠENI SAMOGLASNIKI so se praviloma podaljšali. Danes sta zaradi monoftongizacije nekaterih diftongov nastala kratka naglašena polglasnik in a. Gradivo: go'raca, p'rəča; 'vale, 'moli, 'pala, 'vadla, pra'saca; pog'rap, s'rada, 'late 'leta', 'mala 'imela', ži'va:la, m'la:nčnige, 'apca 'ovca'.

NENAGLAŠENI VOKALI so: $i, u, e, o, a, \partial r$ in so dobro ohranjeni. Nenaglašeni $e$ se izgovarja široko, nenaglašeni $o$ pa ozko.

SOGLASNIŠKI SISTEM je v narečju podoben knjižnemu. Pojavi, ki to narečje ločujejo od drugih štajerskih govorov, so:

- sekundarna nazalizacija vokalov, okrepljena v nosni konzonant; sprožil jo je nosni konzonant na začetku zloga; gradivo: les'nəyka, Lož'nənca, 'məygat, m'la:inko, 'naijki 'neki', 'nən 'ni', ple'nənca, res'nənca, s'naiịk, ž'nəndər; 'mamč, 'pamno, 'žamna 'žolna', 'samce, 'namč;

- razvije se prehodni glas $p$ ali $b$ med $v, t, d, c, \check{c}$; gradivo: 'apca 'ovca', 'bo:upča, 'jo:uptro, 'lo:upč, p'lapt 'plot', p'rapti 'naproti', s'rapta 'sirota'; 
- pojavlja se parazitski j; gradivo: 'dọ:isti, g'rọ:izdje, 'kọiza, 'tu:indi, 'vọizit, $z^{\prime} l o: i$ 'zelo';

- palatalni $l$ ' je prešel v srednji l: 'ko:šl,$k^{\prime}$ ro:l, m'ra:ula;

- palatalni $n$ ' je prešel v nazalni $\bar{j}$, redko pa $\mathrm{v} n$ : čre'pẹi $i \bar{j} a$, 'jiiva, lọ'bo:ja, 'lo:ukna;

- sklop šč se je olajšal v š: 'gọ:ša, k'lariše, šettana;

- zvočnik $v$ se izgovarja $v, u$, pred nezvočnikom ali na koncu besede $\operatorname{kot} f:$ 'vəno, 'vẹ:ime, '̌́ar:f, f'čossi; v je lahko tudi protetičen: 'vơ'uxa, 'vơ'uste, 'vuroves.

\section{2 Živalska frazeologija v oplotniškem govoru}

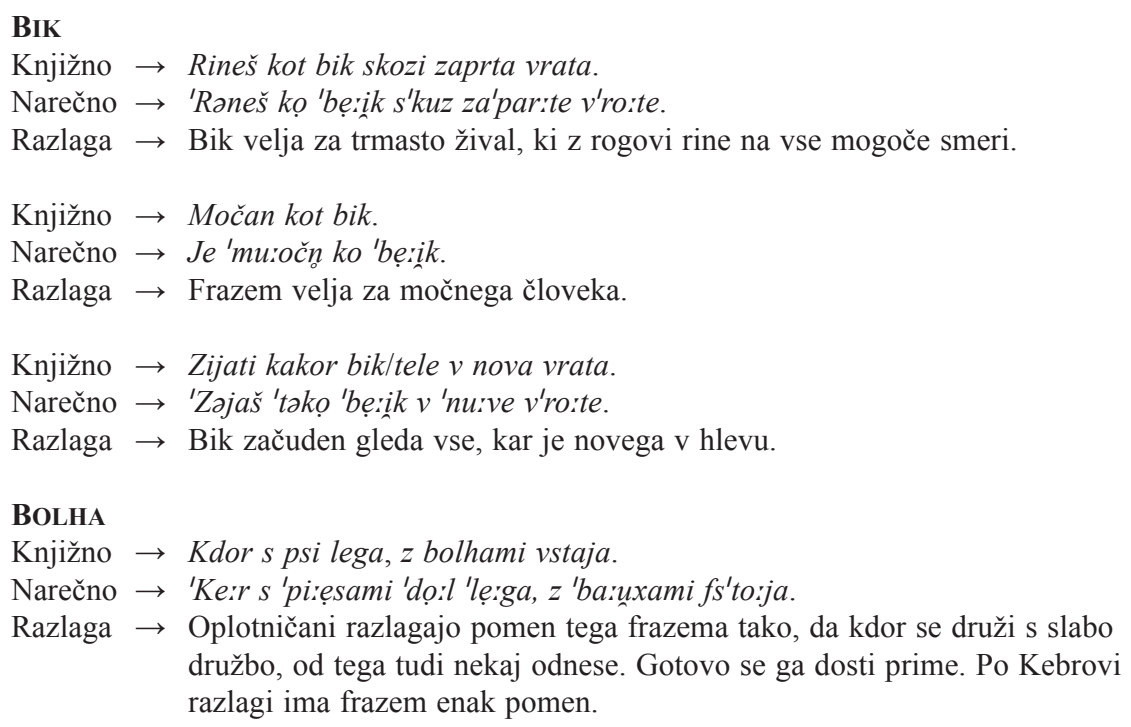

\section{ČEBELA}

Knjižno $\rightarrow$ Biti priden kot čebela.

Narečno $\rightarrow$ Ste p'radni ko čébale.

Razlaga $\rightarrow$ Čebela je žival, ki je v frazeologiji znana predvsem kot delavna, pridna žival.

Knjižno $\rightarrow$ Biti dober kot čebela.

Narečno $\rightarrow$ Ste 'du'obri ko če'bale.

Razlaga $\rightarrow$ Čebela je dobra, ker nabira med in je zato tudi koristna.

Knjižno $\rightarrow$ Živeti kot čebela $v$ medu.

Narečno $\rightarrow$ Bỡ žívou ko če'bala v'mẹdị.

Razlaga $\rightarrow$ Tistemu, ki se mu obeta lepo življenje, rečemo, da bi živel kot čebela v medu.

\section{ČMRLJ}

Knjižno $\rightarrow$ Brenčati kot čmrlj. 
Narečno $\rightarrow$ Bren'čẹ:i ko en čme:u.

Razlaga $\rightarrow$ Čmrlj ima za uho neprijeten zvok, zato tistemu, ki tečnari in godrnja, rečemo, da brenči kot čmrlj.

ČRV

Knjižno $\rightarrow$ Že dolgo ga jedo črvi.

Narečno $\rightarrow$ 'Nirega pa ži 'da:ugu 'čar'vi 'jajo.

Razlaga $\rightarrow$ Ta humorni frazem velja za nekoga, ki je že dolgo mrtev.

Knjižno $\rightarrow$ Imeti črva v glavi.

Narečno $\rightarrow$ 'Tu:ta 'ma: pa 'ra:is 'čarsva v g'larvĭ.

Razlaga $\rightarrow$ Slabšalni frazem velja za nekoga, ki ni posebej pameten. Črv mu je pojedel možgane, zato je sedaj neumen.

\section{DIHUR}

Knjižno $\rightarrow$ Smrdeti kot dihur.

Narečno $\rightarrow$ Smar'dęi ko en di'xuir.

Razlaga $\rightarrow$ Ta slabšalni frazem velja za človeka, ki ima neprijeten vonj. Dihur je žival, ki nenavadno smrdi.

\section{GOLOB}

Knjižno $\rightarrow$ Boljši vrabec v roki kot golob na strehi.

Narečno $\rightarrow$ 'Bu:lši je v'ro:bec v'rọ:ki ko go'lo:p na st'rieexi.

Razlaga $\rightarrow$ Frazem pomeni, da moraš biti zadovoljen s tistim, kar imaš, in ne posegati po nečem večjem.

Gos

Knjižno $\rightarrow$ Biti neumen kot gos.

Narečno $\rightarrow$ 'Baptasta je ko 'go:s.

Razlaga $\rightarrow$ Gos in kura/kokoš imata malo možganov, zato veljata za neumni živali.

Knjižno $\rightarrow$ Za goske ni seno.

Narečno $\rightarrow$ Za'gọske nən 'sieẹno.

Razlaga $\rightarrow$ Če si kdo iz določenega razloga nekaj zelo želi, pa tega ne more dobiti, ker zanj ni primerno.

\section{GOVEDO, ŽIVINA, KRAVA}

Knjižno $\rightarrow$ Biti pravo govedo.

Narečno $\rightarrow$ 'Tir si 'jieẹno go'vẹ:do.

Razlaga $\rightarrow$ Slabšalni frazem za negativnega človeka ali ko ga hoče kdo ponižati.

Knjižno $\rightarrow$ Garati kot črna živina.

Narečno $\rightarrow$ Ga'ro:m ko 'čar:na žvona.

Razlaga $\rightarrow$ Živina trdo dela kot črnec, zamorec.

Knjižno $\rightarrow$ Piti kot krava.

Narečno $\rightarrow$ 'Pi:ješ 'tako 'e:na k'ro:va.

Razlaga $\rightarrow$ Frazem pomeni človekovo obilno, hitro pitje.

Knjižno $\rightarrow$ Biti pijan kot kravalmavra.

Narečno $\rightarrow$ Si 'pi:jen ko k'ro:va. Je 'pi:jen ko 'ma:ura.

Razlaga $\rightarrow$ Mavra je črna krava. 
Knjižno $\rightarrow$ Narediti kravji požirek.

Narečno $\rightarrow$ 'Ze: si pa na'rẹ:du p'ro:vi k'ra:uji po'žirrek.

Razlaga $\rightarrow$ Frazem pomeni, da je kdo napravil dolg požirek.

Knjižno $\rightarrow$ Krava pri gobcu molze.

Narečno $\rightarrow$ K'ro:va por 'go:pci du'je:i $i$.

Razlaga $\rightarrow$ Krmljena krava daje veliko mleka. Več, ko vložiš v kaj, večji je dobiček.

Knjižno $\rightarrow$ Ali ti je krava jezik snedla?

Narečno $\rightarrow$ 'Ko: ti je k'ro:va 'jięzik po'jieẹdla?

Razlaga $\rightarrow$ Frazem pomeni spodbudo k odgovoru.

Knjižno $\rightarrow$ Biti krava neumna.

Narečno $\rightarrow$ Si 'ti: 'ji:ẹna k'ro:va 'nu:ora.

Razlaga $\rightarrow$ Slabšalni frazem za ženski spol je pogost pri prepirih.

Knjižno $\rightarrow$ Imeti dolg jezik kakor krava rep.

Narečno $\rightarrow$ 'Mo:š 'to:k 'jieezilk ko k'ro:va 're:p.

Razlaga $\rightarrow$ Frazem pomeni zelo zgovornega, obrekljivega človeka. Jezik je primerljiv z dolgim kravjim repom.

Knjižno $\rightarrow$ Spoznati se na kaj kot krava na boben.

Narečno $\rightarrow$ Na 'ta:u se pa g'li:x 'tak s'puiozneš ko k'ro:va na 'bo:bn.

Razlaga $\rightarrow$ Frazem se nanaša na človeka, ki o kakšni stvari nima pojma, a se dela pametnega.

Knjižno $\rightarrow$ Nisva krav skupaj pasla.

Narečno $\rightarrow$ 'Čuj 'ti:, 'mi:d'vo: pa 'ni:sma k'ra:u s'ku:p 'po:sla, de bi se 'ti: 'tok z me'no:j 'manu.

Razlaga $\rightarrow$ Frazem uporabljajo starejši ljudje za obrambo pred mlajšimi.

Knjižno $\rightarrow$ Najprej štalica, potem kravica.

Narečno $\rightarrow$ 'Va:išs 'ko:: »'Na:jpre š'ta:lca, 'pol pa k'ra:uca."

Razlaga $\rightarrow$ Mlajši par si mora za skupno življenje najprej priskrbeti dom, tako kot mora kmet za kravo najprej priskrbeti hlev.

\section{KOKOŠ/KURA}

Knjižno $\rightarrow$ Naj me koklja brcne, če lažem.

Narečno $\rightarrow$ Naj me 'ku:ra 'bar'cne, či 'lo:žem.

Razlaga $\rightarrow$ Kokoš ne more človeka brcniti, zato nekdo, ki uporabi ta frazem, gotovo laže.

Knjižno $\rightarrow$ Imeti kurjo polt.

Narečno $\rightarrow$ 'Ma:m kər 'ku:rjo 'ka:užo.

Razlaga $\rightarrow$ Frazem se uporablja, kadar nas zebe ali kadar slišimo kaj presenetljivega, groznega.

Knjižno $\rightarrow$ Je počenil kakor mokra kokoš.

Narečno $\rightarrow$ Se je pu'čẹ:pnala 'təko 'mu:okra 'ku:ra.

Razlaga $\rightarrow$ Frazem velja za človeka, ki bi moral kaj delati, pa se mu ne da in se zato drži zadržano. 
Knjižno $\rightarrow$ Biti kot polita kokoš.

Narečno $\rightarrow$ Je 'to:ka ko pok'ru:pana 'ku:ra.

Razlaga $\rightarrow$ Frazem pomeni primerjavo z mokro kokošjo.

Knjižno $\rightarrow$ Hoditi s kurami spat.

Narečno $\rightarrow$ G'rẹ: s 'ku:rami s'po:t.

Razlaga $\rightarrow$ Frazem pomeni, da gredo kokoši spat ob sončnem zahodu.

Knjižno $\rightarrow$ Tudi slepa kura včasih zrno najde.

Narečno $\rightarrow$ 'Še s'lapa 'kurra f'čorsix 'zar:nu 'ne:de.

Razlaga $\rightarrow$ Frazem izraža uspešno izveden poskus.

Knjižno $\rightarrow$ Hoditi po jajcih.

Narečno $\rightarrow$ 'Xu:dišs 'təkọ po 'jercax.

Razlaga $\rightarrow$ Previdnež ne hodi po zlomljivem predmetu.

Knjižno $\rightarrow$ Biti kot kura brez glave.

Narečno $\rightarrow$ Je ko 'ku:ra brez g'la:ve.

Razlaga $\rightarrow$ Frazem primerja nezanimanje koga za kaj s kuro brez glave, ki še skače sem ter tja.

\author{
KonJ \\ Knjižno $\rightarrow$ Biti močan kot konj. \\ Narečno $\rightarrow$ 'Ja:, 'tuiti je pa 'raiis 'muiọ̌n ko 'ku'oj. \\ Razlaga $\rightarrow$ Frazem kaže na močnega moža. \\ Knjižno $\rightarrow$ Biti kakor konjska figa. \\ Narečno $\rightarrow$ Si na 'cirẹisti 'təko 'kurojska 'fẹ:iga. \\ Razlaga $\rightarrow$ Frazem primerja človeka, ki je pogosto na cesti, s konjsko figo. \\ Knjižno $\rightarrow$ Biti na konju. \\ Narečno $\rightarrow$ 'Ze: pa sn na 'ku:ọiji. \\ Razlaga $\rightarrow$ Velja za človeka, ki je prišel na boljši položaj. \\ Knjižno $\rightarrow$ Beseda ni konj. \\ Narečno $\rightarrow$ Be'sada 'nən 'ku:oj. \\ Razlaga $\rightarrow$ Frazem pomeni, da se tudi dvomljiva beseda izgovori, saj beseda nima \\ take cene kot konj. \\ Knjižno $\rightarrow$ Podarjenemu konju se ne gleda na zobe. \\ Narečno $\rightarrow$ 'Ša:inkanemu 'ku:oju se 'nana g'le:da na 'zo:be. \\ Razlaga $\rightarrow$ Podarjene stvari ne smemo kritizirati. Konj z lepimi zobmi je več vre- \\ den.
}

\title{
KozA
}

Knjižno $\rightarrow$ Ne more biti koza cela in volk sit.

Narečno $\rightarrow$ Sə pa 'tẹ:i 'va:ǐšs, de 'nəna 'muire 'bi:t 'ku:oza 'cala, 'va:uk pa 'sət.

Razlaga $\rightarrow$ Če nam uspe najti rešitev ali kompromis, je za nas spodbudno. 
Knjižno $\rightarrow$ Naučiti koga kozjih molitvic.

Narečno $\rightarrow$ 'Te bom ži nau'čala 'kurozjịx múlistvigc.

Razlaga $\rightarrow$ Frazem izraža misel, da bo kdo koga naučil pameti, reda, ubogljivosti, tudi s tepežem.

Knjižno $\rightarrow$ Biti grešni kozel.

Narečno $\rightarrow$ 'Ze: smu pa 'ne:dli g'ra:išniga 'ku:ozla.

Razlaga $\rightarrow$ Grešni kozel je nekdo, ki je obdolžen za napake drugih.

Knjižno $\rightarrow$ Streljati kozle.

Narečno $\rightarrow$ 'Ta:u je 'tuiti, ko z'me:raj st'rala 'to:ke 'kurozle.

Razlaga $\rightarrow$ Frazem pomeni, da kdo dela velike napake, neumnosti.

\section{KRT}

Knjižno $\rightarrow$ Iti v krtovo deželo.

Narečno $\rightarrow$ Za'tisstiga, ko je úmar', se 'rię̣če, de je 'ša:u f'kar:tuvo de žirẹ:lo.

Razlaga $\rightarrow$ Primerjava je primerna za nekoga, ki umre.

Knjižno $\rightarrow$ Riješ kot krt.

Narečno $\rightarrow$ 'Rẹ:iješ ko 'kar:t.

Razlaga $\rightarrow$ Frazem pomeni nekoga, ki na zemlji vedno nekaj razkopava.

\section{LISICA}

Knjižno $\rightarrow$ Biti zvit kot lisica.

Narečno $\rightarrow$ Je z'vata ko li'saca.

Razlaga $\rightarrow$ Frazem pomeni zvitega, prebrisanega človeka.

\section{MAČEK}

Knjižno $\rightarrow$ Gledata se kot pes in mačka.

Narečno $\rightarrow$ Se g'lẹ:data 'təko 'pires pa 'mo:čka.

Razlaga $\rightarrow$ Frazem velja za osebi, ki izmenjata sovražen pogled, ker se ne razumeta.

Knjižno $\rightarrow$ Igrati se s kom kot mačka z mišjo.

Narečno $\rightarrow$ Se špala ž 'ji:m 'təko 'mo:čka z 'mẹ:išsjo.

Razlaga $\rightarrow$ Frazem pomeni imeti nekoga v popolni oblasti.

Knjižno $\rightarrow$ Kadar mačke ni doma, miši plešejo.

Narečno $\rightarrow$ 'Tẹ:, ko 'mo:čke 'nən 'duroma, 'mẹ:ǐši p'lẹ:šejo.

Razlaga $\rightarrow$ Frazem pomeni, da če mačke ni v bližini, miši prosto rajajo/plešejo.

Knjižno $\rightarrow$ Hoditi kakor mačka okrog vrele kaše.

Narečno $\rightarrow$ 'Xu:dí 'tako 'mo:čka o'ku:l v'ri:le 'ko:še.

Razlaga $\rightarrow$ Frazem pomeni, da bi kdo rad nekomu nekaj povedal, zlasti ker gre za novico, ob kateri bi se govorec lahko opekel.

Knjižno $\rightarrow$ Če mački na rep stopiš, zacvili.

Narečno $\rightarrow \check{C}_{i}$ 'mo:čki na 'rẹ:p s'to:piš, zac'vali.

Razlaga $\rightarrow$ Frazem pomeni, da nekoga prizadenemo, če vemo, kje je najobčutljivejši. 
Knjižno $\rightarrow$ Imeti/preganjati mačka.

Narečno $\rightarrow$ 'Ko: 'ni'ess pa 'mo:čka pre'go:jaš?

Razlaga $\rightarrow$ Po neprespani, pijani noči je človek neprespan, mlahav.

Knjižno $\rightarrow$ Kupiti mačka $v$ žaklju.

Narečno $\rightarrow$ 'Ze: si pa 'kapu'mo:čka v 'žo:kli.

Razlaga $\rightarrow$ Frazem izraža napačen nakup.

\section{MEDVED}

Knjižno $\rightarrow$ Spati kot medved.

Narečno $\rightarrow$ Za 'jireniga, ko 'fẹrist s'pẹii, se 'rirẹce, da s'pẹ:i 'təko 'mirẹidved.

Razlaga $\rightarrow$ Ta frazem spoznajo že otroci v pravljicah o zaspanih medvedih.

\section{MIš}

Knjižno $\rightarrow$ Biti tiho kot miš.

Narečno $\rightarrow$ Si 'tẹ:ixo 'tako 'ji:ẹna 'mi:š.

Razlaga $\rightarrow$ Za miši je značilno, da so tihe živali.

Knjižno $\rightarrow$ Zagledati bele miši.

Narečno $\rightarrow S^{\prime}$ 'tu:tim je pa 'tək 'ferrtik. 'Ze: 'ži jo 'bale 'mẹ:ǐsi 'vadi.

Razlaga $\rightarrow$ Pijanec, odvisen od alkohola, se mora zdraviti.

\section{MraVlJA}

Knjižno $\rightarrow$ Delati kot mravlja.

Narečno $\rightarrow$ Za'ti:stiga, ko 'fẹisst 'dala, se 'rieẹce, de 'dala 'toko m'ra:ula.

Razlaga $\rightarrow$ Mravlja je pridna žival.

Knjižno $\rightarrow$ Imeti mravlje v riti.

Narečno $\rightarrow$ Či 'korko 'urotrok kar še'mẹiče, 'riačemo, da 'mo: m'ra:ule v'ratị.

Razlaga $\rightarrow$ Nemirnež se kar preseda.

\section{MuHA}

Knjižno $\rightarrow$ Biti siten kot podrepna muha.

Narečno $\rightarrow$ Si 'satn 'təko pud'rẹ:pna 'mo:uxa.

Razlaga $\rightarrow$ Frazem kaže na sitnega človeka.

\section{Mula}

Knjižno $\rightarrow$ Delati kot mula.

Narečno $\rightarrow$ 'Dala 'təko 'mo:ula.

Razlaga $\rightarrow$ Mula velja za pridno, delavno žival. Ta frazem je na južnem Pohorju pogost.

\section{OPICA}

Knjižno $\rightarrow$ Skakati kot opica.

Narečno $\rightarrow$ S'ko:češ 'təko 'ji:enna 'o:pica.

Razlaga $\rightarrow$ Človek, ki rad pleše, skače, je podoben opici.

\section{OSA}

Knjižno $\rightarrow$ Biti hud/siten/razdražen kot osa.

Narečno $\rightarrow$ Za 'tẹ:čnega al pa 'satniga 'ri:ẹčemo, da je razd'ro:žen 'təko 'urosa. 
OSEL

Knjižno $\rightarrow$ Kjer osel leži, dlako pusti.

Narečno $\rightarrow$ 'Ta:m, ko 'urosu le'žẹ:i, d'lo:ko pus'tẹi.

Knjižno $\rightarrow$ Osle kazati komu.

Narečno $\rightarrow$ 'Ta:u nən 'lapu, če 'jię̣nemu 'u'osle pu'ko:žeš.

Razlaga $\rightarrow$ Otroci komu pokažejo jezik in si pomagajo z gibi rok.

\section{OvCA}

Knjižno $\rightarrow$ Biti črna ovca $v$ družini.

Narečno $\rightarrow$ 'Ze: je pa 'uron 'čar:na 'apca is'po:du.

Razlaga $\rightarrow$ Frazem velja za odrinjenega človeka iz družbe.

PES

Knjižno $\rightarrow$ Boj se tistega, ki spredaj liže, zadaj praska.

Narečno $\rightarrow$ 'Mareš se 'ba:t 'tistiga 'pi:ẹsa, ko sp'rada 'lẹ:iže, 'zo:da pa g'rẹ:ize.

Razlaga $\rightarrow$ Takšen pes je hudoben, prav tako tudi človek, ki je nevaren in ne prinaša nič dobrega.

Knjižno $\rightarrow$ Zebsti kot psa.

Narečno $\rightarrow$ Či 'ku'oga 'fẹinst 'zẹ:be, 'riẹčemu, de ga 'zẹ:be 'toko 'piresa.

Knjižno $\rightarrow$ Še pes ima rad pri jedi mir.

Narečno $\rightarrow$ Še 'pirẹs 'mo: 'ra:d pri 'issti 'mirr.

Razlaga $\rightarrow$ Frazem izraža pasjo lastnost, da bo ukrepal, če ga kdo razdraži.

Knjižno $\rightarrow$ Pes, ki laja, ne grize.

Narečno $\rightarrow$ 'Tirsti 'pirẹs, ko 'lo:ja, 'nana g'rẹ:ize.

Knjižno $\rightarrow$ Vedeti, kam pes taco moli.

Narečno $\rightarrow$ 'Jiress sn tək'vadla, kam 'pi:ẹs 'torco mu'lẹi

Razlaga $\rightarrow$ Človek ve, kaj ima kdo za bregom.

\section{Petelin}

Knjižno $\rightarrow$ Hoditi kakor petelin.

Narečno $\rightarrow$ 'Xu'di 'takọ en pe'tieelin.

Razlaga $\rightarrow$ Primerjava velja za ošabnega človeka.

\section{PiKAPOLONICA}

Knjižno $\rightarrow$ Biti kot božji volek.

Narečno $\rightarrow$ 'Tusti je pa p'ro:vi 'bu:ožji 'vurolek.

Razlaga $\rightarrow$ Izraz pomeni pikapolonico, označuje pa pohlevnega, mevžastega človeka,

\section{PoLž} ki pa vse vzame za dobro.

Knjižno $\rightarrow$ Se sliniš kot polž.

Narečno $\rightarrow$ Se s'lanišs 'təko 'pa:ušs.

Razlaga $\rightarrow$ Okrog ust so večkrat mokri otroci, pa tudi pijančki. 


\title{
PTICA
}

Knjižno $\rightarrow$ Živeti kakor ptiček na veji.

Narečno $\rightarrow$ 'Ze: pa ži'vẹi 'təko p'təč na 'vi:ji.

Razlaga $\rightarrow$ Tak človek živi brezskrbno, veselo življenje.

\section{RAK}

Knjižno $\rightarrow$ Iti rakom žvižgat.

Narečno $\rightarrow$ Za 'tisstiga, ko se mu b'leriža 'ku'onec, se 'rieẹcče, do bo 'šau 'ra:kom žvẹi:ižgat.

Razlaga $\rightarrow$ Frazem pomeni umreti.

\section{RIBA}

Knjižno $\rightarrow$ Biti zdrav kot riba.

Narečno $\rightarrow$ Je zd'ra:u ko 'raba.

Razlaga $\rightarrow$ Riba velja za zdravo žival.

\section{SLON}

Knjižno $\rightarrow$ Delati iz muhe slona.

Narečno $\rightarrow$ Či 'ke:r preti'ra:va, 'ri:ẹčemu, de 'dala z 'mo:uxe s'lưọna.

Razlaga $\rightarrow$ Frazem pomeni pretiravanje.

\author{
SRAKA \\ Knjižno $\rightarrow$ Krasti kot sraka. \\ Narečno $\rightarrow$ K'ro:de 'təko s'ro:ka. \\ Razlaga $\rightarrow$ Sraka velja za kradljivko. \\ Knjižno $\rightarrow$ Dreti se kot sraka. \\ Narečno $\rightarrow$ Se 'diẹre ko s'rọ:ka. \\ Razlaga $\rightarrow$ Frazem pomeni človeka, ki vrešči, vpije, se dere.

\section{SRŠEN} \\ Knjižno $\rightarrow$ Imeti sršene $v$ riti. \\ Narečno $\rightarrow$ Čj 'nəmaš 'nič 'mirra, je g'lixx 'tək, ko bi 'mi:ẹli sar'širẹe v'rati. \\ Razlaga $\rightarrow$ Frazem predstavlja nemirnega človeka.

\section{SVINJA} \\ Knjižno $\rightarrow$ Biti debel kot prašič. \\ Narečno $\rightarrow$ 'Tissti, ko je 'fẹ:ist 'diẹbo, je 'tako p'ra:šič. \\ Razlaga $\rightarrow$ Frazem primerja človeka s svinjo. \\ Knjižno $\rightarrow$ Ričet je boljši, če je prašič vanj stopil. \\ Narečno $\rightarrow$ 'Ri:čet bi 'biu 'builši, či bi p'raišič 'nat s'to:pu. \\ Knjižno $\rightarrow$ Biti pijan kot svinja. \\ Narečno $\rightarrow$ Či je 'ke:r 'fẹ:ist 'pi:jen, 'rirẹčemu, da je 'pi:jen ko p'raise. \\ Razlaga $\rightarrow$ Frazem pomeni nečistočo pri svinji, pijan človek namreč smrdi, je \\ popackan, polit. \\ Knjižno $\rightarrow$ Ravnati s čim kot svinja z mehom.

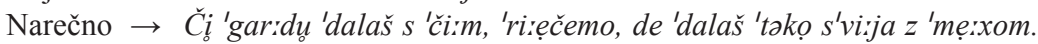




\section{ŠTORKLJA}

Knjižno $\rightarrow$ Štorklja ti bo prinesla bratca.

Narečno $\rightarrow$ Ut'ru:okam 'riẹčemo, de jih je što:rkla par'ni:ẹla.

Razlaga $\rightarrow$ Frazem kaže na staro reklo, da štorklja prinaša otroke.

\section{TELE}

Knjižno $\rightarrow$ Vsako tele ima svoje veselje.

Narečno $\rightarrow F^{\prime}$ so:ko 'tirẹle 'mo: s'vuroje ve'sirelje.

Razlaga $\rightarrow$ Keber razlaga, da gre za pravico mladih, nezrelih in nespametnih. Frazem izraža dopuščanje neprimernega ravnanja.

\section{Uš}

Knjižno $\rightarrow$ Jesti kot uš.

Narečno $\rightarrow P a$ 'tuit 'jai išs 'təko 'jirẹ:na 'urš.

Razlaga $\rightarrow$ Uš vedno je, zato takšna primerjava.

\section{ZAJEC}

Knjižno $\rightarrow$ Bežati kot zajec.

Narečno $\rightarrow$ Je z'ba:ižau ko en 'zẹ:c.

Razlaga $\rightarrow$ Zajec je urna in tudi bojazljiva žival.

Knjižno $\rightarrow$ Vedeti, v katerem grmu tiči zajec.

Narečno $\rightarrow$ Či 'vamu, za 'ko: se g'rẹ:, na'vo:dno 'rieẹcemu, de žj 'vamu, f'kẹrem 'gar:mi tíč́e:i 'zẹ:c.

Razlaga $\rightarrow$ Frazem pomeni, da nam je rešitev uganke dobro znana.

\section{ŽABA}

Knjižno $\rightarrow$ Napihovati se kot žaba.

Narečno $\rightarrow$ Se napi'xọ:uje ko 'žo:ba.

Razlaga $\rightarrow$ Frazem se nanaša na človeka, ki hoče biti v središču pozornosti.

ŽOLNA

Knjižno $\rightarrow$ Piti kot žolna.

Narečno $\rightarrow$ Za 'ti:stiga, ko 'fẹ:int 'pi:je, se 'ri:ẹče, de 'pi:je ko 'žoruna.

Razlaga $\rightarrow$ Žolna vedno kliče dež. V prenesenem pomenu se izraz žolna uporablja za označevanje pijanca.

\subsection{Posebna poimenovanja za živali v oplotniškem govoru}

- 'apca 'ovca';

- 'ba:jpka 'zajklja'; 'ma:ndllc 'zajec' (m. sp.);

- 'badar 'oven';

- 'buiơzji 'vuiọlek 'pikapolonica';

- 'cirek 'klop';

- 'ča:ila 'čebela';

- 'čoruyka, 'čorükec 'svinja';

- 'xa:bux 'jastreb';

- kost'ro:mn 'oven';

- 'kiẹbar 'hrošč';
- 'ko:ura 'kokoš';

- 'lorrbeki ('apčji, 'ko:izji) 'živalsko govno';

- 'ma:ca ‘čebelja matica';

- mara'so:k, ma'rasisec 'merjasec';

- m'ro:mur 'bramor';

- 'reica 'raca';

- 'sarišo, sar'śieẹla 'sršen';

- št'rẹitigla 'strigalica';

- 'uil 'čebelnjak'; 'zẹcc 'zajec'. 


\section{3 Živalski frazemi v Pleteršnikovem Slovensko-nemškem slovarju}

bolha, f. - der Floh $\rightarrow$ bolha me pika, je; bolhe loviti;

čebela, f. - die Bine $\rightarrow$ čebele gredo na zbir; čebela piči; čebele mrejo (Cigale);

črv, m. - der Wurm $\rightarrow$ črve pasti 'mrtev biti'; črv na prstu;

fíga, f. - die Fiege $\rightarrow$ konjska figa; figo komu kazati;

govedo:

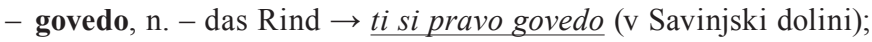

- živina, f. - das Vieh $\rightarrow$ neumen kakor živina; delati kakor črna živina;

- krava, f. - das Kuh $\rightarrow$ kamor je šla krava, naj gre še tele;

- mavra, f. - eine schwarzgestreifte Kuh $\rightarrow$ ponoči je vsaka krava mavra;

- bìk, bíka, m. - der Stier $\rightarrow$ pojdi se z bikom bost;

kača, f. - die Schlange $\rightarrow$ mrzel kakor kača; jača kača;

kònj, kónja, m. - das Pferd $\rightarrow$ na konju biti; močen kakor konj; dela kakor konj;

koza, f. - die Ziege $\rightarrow$ ne more biti koza cela in volk sit;

kr̀t, kŕta, m. - der Maulwurf $\rightarrow$ boji se dneva kakor krt;

lisíca, f. - der Fuchs $\rightarrow$ vsaka lisica svoj rep hvali; lisici na rep sesti;

mâčka, f. - die Katze $\rightarrow$ kakor mačka okoli vrele kaše hoditi; mačko v vreči (žaklju) kupiti; gledati se kakor pes in mačka; kar mačka rodi, rado miši lovi; tak si kakor breja mačka;

miš, f., - die Maus $\rightarrow$ moker kakor miš; ni ptič ni miš; slepe miši loviti;

mravlja, f. - die Ameise $\rightarrow$ mravlje mi lezejo po životu; mravlje me obletajo; mravlje so me obsule;

múha, f. - die Fliege $\rightarrow$ siten kakor muha; podrepna muha 'muha, ki živini pod rep sili'; muhe v glavi imeti;

mùla, n. - das Maulthier $\rightarrow$ mulo nositi; mulo pasti;

ósel, -sla, m. - der Esel $\rightarrow$ tudi psovka; osle moliti ali kazati komu;

pès, psà, m. - der Hund $\rightarrow$ psu zvoniti; gledata se ali dobra sta si kakor pes in mačka; nas se pes obesi; lačen je kakor pes; še pes ga ne povoha; vem, kam pes taco moli; dober je krajcar, če ga pes na repu prinese;

petélin, petelína, m. - der Hahn $\rightarrow$ ošaben kakor petelin na gnoju;

pólž, m. - die Schnecke $\rightarrow$ počasi hodi kakor polž;

prasè, prasẹ́ta, n. - ein junges Schwein $\rightarrow$ psovka: ti prase, ti;

ptica, ptì̌, f., m. - der Vogel $\rightarrow$ ni ptič ni mišs; pravi ptič je;

ríba, f. - der Fisch $\rightarrow \underline{\text { zdrav je kakor riba; }}$

sŕna, f. - das Reh $\rightarrow$ skače kakor srna; nositi se kot srna, pa nema zrna;

sŕšen, -ẹ́na, m. - die Hornis $\rightarrow$ leti, kakor bi ga sršeni lovili; sršene v glavi imeti; sršene dražiti;

${ }^{2}$ Frazemi, izpisani iz Pleteršnikovega slovarja, so zapisani v ležeči pisavi in podčrtani. 
vôlk, vôlka, m. - der Wolf $\rightarrow$ volk sit pa koza cela ne more biti; mi o volku, volk pa iz lesa; volk biti na kako jed;

vrabec, -bca, m. - der Sperling $\rightarrow$ ima vrabca pod klobukom 'noče se odkrivati';

vrân, vrána, f. - die Krähe $\rightarrow$ vrana vrani oči ne izkljuje (izkoplje);

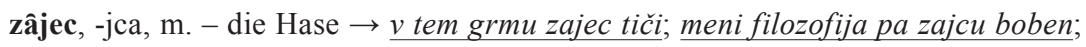

žába, f. - der Frosch $\rightarrow$ žaba se reka malim otrokom: »Oj, ti žaba mala, ti!«.

\section{Sklepne misli}

V prvem delu prispevka sta na glasoslovni ravni predstavljena štajerska južnopohorska govora Mislinje in Oplotnice.

Govor Mislinje je na Karti slovenskih narečij (1993) označen na vzhodni meji koroškega mežiškega narečja ob štajerskih južnopohorskih govorih in štajerskem srednjesavinjskem narečju, a njegova današnja narečna podoba $\mathrm{v}$ glasoslovju kaže na štajersko podstavo, saj je samoglasniški sistem podoben južnopohorskemu s tipičnima štajerskima dvoglasnikoma (e:i in oru). Mislinjski

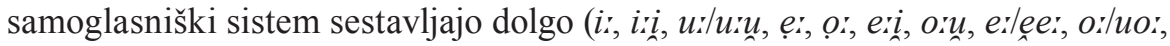
ar:) in kratko naglašeni samoglasniki ter nenaglašeni samoglasniki, ki so dobro ohranjeni. V soglasniškem sistemu se govor od knjižnega loči le v nekaterih premenah, ki so natančneje predstavljene.

Govor Oplotnice je štajerski južnopohorski govor, ki ima že več dvoglasnikov (i:e, uro, e:i, o:u, a:i, a:u). Govor kaže nagnjenje k diftongizaciji dolgih vokalnih fonemov, enoglasniki pa so srednje dolgi, vendar jih označujemo z dvopičjem, saj sta kratko naglašena le polglasnik in $a$. Kratki naglašeni samoglasniki so se praviloma podaljšali, kratki polglasnik in kratki a pa sta nastala po monoftongizaciji nekaterih diftongov. Soglasniški sistem je podoben knjižnemu; pojavi, ki to narečje ločujejo od drugih štajerskih govorov, so opredeljeni.

$\mathrm{V}$ drugem delu prispevka je preučenih in zapisanih 91 živalskih frazemov v štajerskem južnopohorskem narečju Oplotnice, in sicer za naslednjih 43 živali: bik, bolha, čebela, čmrlj, črv, dihur, golob, gos, govedo (živina, krava), kokoš/ kura, konj, koza, krt, lisica, maček, medved, miš, mravlja, muha, mula, opica, osa, osel, ovca, pes, petelin, pikapolonica, polž, ptica, rak, riba, slon, sraka, sršen, svinja, štorklja, tele, uš, zajec, žaba, žolna. Frazemi so najprej zapisani v knjižni, nato v narečni obliki, dodana jim je tudi kratka razlaga. Nato sledi zapis še 20 narečnih posebnih poimenovanj za živali v obravnavanem govoru.

Zadnji, tretji del prispevka je posvečen analizi živalske frazeologije v Slovensko-nemškem slovarju Maksa Pleteršnika. Ugotovljeno je, da pri iskanih 61 geslih za živali v tem slovarju najdemo 65 frazemov, ki se nanašajo nanje, in sicer pri naslednjih slovarskih člankih: bolha (2), čebela (3), črv (2), figa (2), govedo (6 $\rightarrow$ govedo: 1, živina: 2, krava: 1, mavra: 1, bik: 1), kača (2), konj (3), koza (1), krt (1), lisica (2), mačka (5), miš (3), mravlja (3), muha (3), mula (2), osel (1), pes (7), petelin (1), polž (1), ptica (2), riba (1), srna (2), sršen (3), volk (3), vrabec (1), vran (1), zajec (2). 


\section{VIRI IN LITERATURA}

Janez KEBER, 1996: Živali v prispodobah 1. Celje: Mohorjeva družba.

--, 1998: Živali v prispodobah 2. Celje: Mohorjeva družba.

Tine LOGAR, 1956: Prispevek h klasifikaciji pohorskih govorov. Slavistična revija 9, $30-34$.

- -, 1959: Dialektična podoba Pohorja. Razprave [Razred 2]. Razred za filološke in literarne vede 5, 81-90.

- -, 1975: Slovenska narečja. Ljubljana: Mladinska knjiga.

Tine LOGAR, Jakob RIGLER, 1993: Karta slovenskih narečij. Ljubljana: Geodetski zavod Slovenije.

- -, 2001: Slovenska narečja. Nacionalni atlas Slovenije [kartografsko gradivo], 1. zvezek. Ljubljana: Rokus. 119.

Nataša OČKO, 2002: Živalska frazeologija v oplotniškem govoru. Diplomsko delo. Maribor: Pedagoška fakulteta.

Lea ODER, 2003: Mislinjski govor. Diplomsko delo. Maribor: Pedagoška fakulteta.

Maks PLETERŠNIK, 1894: Slovensko-nemški slovar. Ljubljana: Knezoškofijstvo.

- -, 2006: Slovensko-nemški slovar (1894-1895). Transliterirana in elektronska izdaja. Ljubljana: Inštitut za slovenski jezik Frana Ramovša, Založba ZRC.

Fran RAMOVŠ, 1935: Historična gramatika slovenskega jezika VII. Dialekti. Ljubljana: Učiteljska tiskarna.

Jože TOPORIŠIČ, 1992: Enciklopedija slovenskega jezika. Ljubljana: Cankarjeva založba.

Zinka ZORKO, 1998: Haloško narečje in druge dialektološke študije. Maribor: Slavistično društvo. (Zora 6).

--, 2009: Narečjeslovne razprave o koroških, štajerskih in panonskih govorih. Maribor: Filozofska fakulteta, Mednarodna založba Oddelka za slovanske jezike in književnosti. (Zora 64).

\section{ANIMAL PHRASEMES IN THE STYRIAN SOUTH POHORJE DIALECT}

The paper analyses animal phrasemes in the Styrian South Pohorje dialect of the Oplotnica dialect in Pleteršnik's Slovensko-nemški slovar. The lexical units for animal names pertain to domestic animals such as a flea, bull, bee, bumblebee, worm, skunk, pigeon, goose, snake, hen, horse, goat, cow, mole, fox, cat, bear, mouse, ant, fly, wasp, donkey, sheep, dog, ladybird, snail, bird, crab, elephant, magpie, hornet, swine, stork, louse, rabbit, frog and woodpecker. In some cases, dialectal expressions for the animal names are presented as well. The phrasemes are first written in the literary (i.e. standard) form and then in dialectal form. 
The Mislinja dialect is classified as a Styrian dialect as it has developed a long conso-

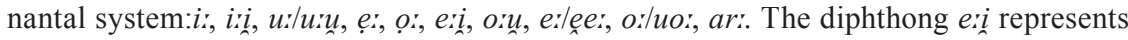
the circumflexed jat and the long etymological $e$, while the diphthong o: $u$ mirrors the long circumflexed $o$. The wide $o:$ represents the always long $a$ : The consonantal alternations are the following: the softened $l j$ has lost its palatality, while the softened $n j$ lost its nasality; the sonorant $j$ pushes its way before $d, g, s$; the clusters $d l$ and $d n$ are preserved, while the word-final $-g$ is pronounced as the fricative $x$.

The Oplotnica dialect abounds in more diphthongs: i:e, uro, e:i, o: $u$, a: $i, a^{\prime} u$. The sound ire represents the umlauted stressed $e$ and a semi-vowel, u:o is a reflex of the umlauted stressed $o$, eri reflects the long $i$, the vowel or $u$ mirrors the sound $u_{i}$, a: $i$ reflects the always long jat and the long etymological $e$, while a: $u$ mirrors the long etymological $o$. As in the Mislinja dialect, the long wide $o$ : evolved from the long $a$ : sound. Short stressed vowels are normally prolonged, whereas short semi-vowels and the short $a$ sound developed in the process of monophthongization of some diphthongs. The consonantal system exhibits secondary nasalization as well.

The vocabulary items reveal some peculiar expressions in naming animals. In Pleteršnik's Slovensko-nemški slovar the animal phrasemes in brackets complement some of the lexical units naming animals, for example a bull, flea, bee, worm, snake, horse, goat, mole, cow, fox, cat, mouse, mule, ant, bird, hornet, wolf, sparrow, magpie, rabbit and a frog. 